\title{
Food Security Via Improving Crop Water Productivity in Some Arab Countries
}

\author{
Nassar Atef ${ }^{1 *}$ and Fawzy Gamal ${ }^{2}$ \\ ${ }^{1}$ Deputy of Water Management Research Institute, Egypt \\ ${ }^{2}$ Water Management Research Institute, Egypt
}

*Corresponding author: Nassar Atef, Deputy of Water Management Research Institute, Egypt.

Received Date: April 26, 2019

Published Date: May 08, 2019

\begin{abstract}
Food security is one of the essential elements of national security, and self-sufficiency in basic food commodities, Arab countries import about half of their food requirements and are considered the significant importers of grain in the world. On this basis, Arab countries, particularly those with vast agricultural capabilities, have worked on achieving the goal of self-sufficiency, reducing the food gap, and have implemented many national plans and programs to increase production and productivity within the agricultural sector.
\end{abstract}

Water availability in the Arab region is a critical issue as the region has 5 percent of the world's population having access to merely 1 percent of the world's total water resources. According to United Nations estimates, around 12 Arab countries suffer from severe water shortages. The per capita availability of renewable water resources is less than $500 \mathrm{~m} 3$ per year.

In General, the majority of Arab countries has a shortage of rainfall, agriculture and its development are almost entirely dependent on irrigation; therefore, the Socio-Economic growth is closely linked to a well-planned improvement of irrigation.

The food consumption pattern is expected to change dramatically during the next 20 years in response to increases in population, per capita income and changes in consumer preferences. This study provides evidence on the importance of studying food security alongside water poverty. Having water scarcity contributing to nearly half the variation in food security will have an important policy, research, and investment implications. The agricultural sector faces the challenge to produce more food with less water by increasing crop water productivity. Higher water productivity results in either the same production from fewer water resources, or a higher production from the same water resources, so this is of direct benefit for other water users.

This paper contributes to the debate and aims at explaining the efficient use of water for food production and identifying opportunities and challenges to produce more food with less water by increasing crop water productivity. The study presented several options to achieve the strategy of food security via improving water productivity. Some measures were provided to adopt these options to the local circumstances and guarantee the Arab states' right to achieving food security for their people.

Keywords: Food security; Food gap; Water productivity; Food consumption; Water scarce

\section{Introduction}

The Arab Organization for Agricultural Development defines Food Security as continuously providing all members of the society with food in quantity and quality necessary for their activity and good health, depending first on local food production, second on the basis of comparative advantage for the production of food commodities in each country and third on the availability of food to the citizens at prices that are suitable to their incomes. On the other hand, the Food and Agriculture Organization asserts that food security is achieved when all the individuals, at times, possess the necessary economic and social capacity to have access to adequate and safe food components to meet their food needs and preferences, in order to enjoy an active and healthy life.

The Arab region is one of the acridest regions in the world and consequently faces enormous food security and food sovereignty challenges. Limited cultivated land and water resources are major constraints on agricultural development and food production. As a consequence, Arab countries are highly dependent on imported foods, particularly basic foods such as cereals that are the regular 
diet of the poor. With the projected increase in population, the demand for food-for human consumption as well as animal feed-is expected to grow substantially. The challenge for the future is to find the best ways to improve food security while recognizing that there will be continued and increasing dependence on imports.

The irrigation sector is the largest consumer of available water, as it uses about 187 billion $\mathrm{m}^{3}$ of water annually to irrigate about 14 million ha. Irrigated agriculture is mainly in Egypt, Sudan, Iraq, Syria, Morocco, Algeria, and Saudi Arabia, with a total irrigated area of about 12 million ha, or approximately 85 percent of the total irrigated area in the Arab World. Confronted with worsening conditions of expanding food gap during the seventies, the Arab countries, especially those with high agricultural potential, accelerated the process of surface and groundwater mobilization mostly for expanding irrigation. The past three decades witnessed intensive exploitation of groundwater, including, non-renewable water, and construction of a large number of dams, especially in Iraq, Syria, Morocco, Algeria, Sudan, and Tunisia. This was accompanied by an expansion in irrigated areas, where the total of such areas increased from about 9.5 million ha in 1980 to approximately 14.2 million ha in 2008.

Water has contributed significantly to the reduction of the food gap and helped achieve self-sufficiency in vegetables and fruits. The water use in agriculture in the Arab World is generally characterized by low efficiency, where conventional surface irrigation (about 80 percent of the irrigated area) is the dominant system, particularly in countries of major agricultural production. Some Arab countries, during the past three decades, have introduced modern systems for irrigation, but the percentage of irrigated areas equipped with modern irrigation systems are still limited in most of the Arab World except for Gulf countries, Jordan and Tunisia.

Arab countries import about half of their food requirements and are considered the major importers of grain in the world. Three countries (Egypt, Algeria, and Morocco), although among the most important producers of grain, are also among the top ten importers of wheat in the world. The Arab countries import more than half of their grain, about 72 percent of sugar, 68 percent of vegetable oil, 31 percent of dairy products, and 14 percent of meat needs. Thus, the food gap has increased, as the net value of food imports increased from $\$ 10.2$ billion U.S. in 1980 to $\$ 28$ billion U.S. In 2009, and out of the $\$ 16.3$ billion the U.S. of grain imports, more than half was wheat. It is expected that the value of this gap will reach $\$ 80$ billion U.S. by the year 2030 .

Based on domestically produced food, especially cereals, whose self-sufficiency ratio dropped from about 50 percent in 2005 to about 46 percent in 2011. Regionally, the Arab countries were nearly self-sufficient in fruits and vegetables, and fish, but had a self- sufficiency ratio of 45.55 percent in cereals, 54.35 percent in oils and fats, and 36.85 percent in sugar in 2011.

Table 1 summarizes the development of self-sufficiency ratios for the most important groups of food commodities in the Arab countries between 2005 and 2011. Cereals are of special significance to food security in Arab countries, because they are the main staple food and feed for livestock.

Table 1: Food Self-sufficiency in Arab countries (\%).

\begin{tabular}{|c|c|c|}
\hline Food Commodity & $\mathbf{2 0 0 5}$ & $\mathbf{2 0 1 1}$ \\
\hline Cereals & 49.74 & 45.55 \\
\hline Sugar & 38.47 & 36.85 \\
\hline Fats \& Oils & 28.12 & 54.35 \\
\hline Meat & 80.8 & 76.19 \\
\hline Fruits \& Vegetables & 98.49 & 106.19 \\
\hline Fish & 103.09 & 98.19 \\
\hline Other Commodities & 77.78 & 82.5 \\
\hline Average & 70.48 & 71.69 \\
\hline
\end{tabular}

Source: [15], the state of food security and agricultural resources [16].

\section{Research Problem}

With increasing the population and the fixed of the water available for agricultural production, the food security for the future generation is at stake. The agricultural sector faces the challenge to produce more food with less water by increasing crop water productivity. Arab countries suffered from the lack of qualified and the preparation of human resources, low funds, and the lack of modern techniques to avoid the negative impact of climate change. All these reasons mentioned above, led to the fragility of investment in the agricultural sector, as investors prefer to invest in other activities such as services and manufacturing sectors, due to inadequate water resources and technical capabilities [1].

So, the problem is the absence of a comprehensive and integrated vision for irrigation and agriculture, and the lack of strategies and specific programs to manage both sectors have adversely affected their performance in many Arab countries.

The functions of several institutions and various government bodies overlap in the management of water without adequate coordination. These results in fragmentation of the regulatory framework and laws relating to the irrigation of agriculture sectors are led to weak and improper planning and management of water. There is a need for coordination of irrigation and agriculture sectors policies in a context of clear strategies and targets, which will improve the allocation of water resources and the efficiency of their use.

\section{Objectives of the Study}

This study aims to evaluate the impact of food security as an essential, and useful axis in providing political, social security, and stability in the Arab regions. The Arab States suffer from the shortage of food goods, and the nutrition subordination to meet the needs of their people. This study also concentrates on the reality of food security, and the various challenges that encounter the sustaining of food security and self-efficiency for the Arab states. It is significant because it investigates the political and social dimensions, which represent the reality of food security and its relationship with water security in the Arab World. Accordingly, the objective of this study can be summarized as follows: 
Recognizing the reality of food security in the Arab World.

1. Explaining the various concepts of water productivity, and critically reviews the available data on water productivity, in general, physical and economic terms, for major crops at different spatial scales.

2. High lighting the most significant challenges and threatens that face food security.

3. Improving the productivity of existing water resources is a vital aspect to face the increasing population.

4. The necessity for having strategies and regulations that guarantee the Arab states' right in achieving food security for their people.

\section{The Methodology of the Study}

The study draws on the descriptive approach in explaining the real situation of the event or the problem by defining its circumstances, dimensions, and explaining the relationships between them. The descriptive approach focuses on analytical methods that rest on adequate and accurate information about a phenomenon or a subject during a specific period, to get scientific results, and to explain it in a subjective way lining with the actual data of the event. The study focuses on available data and information to understand and to describe the research problem by resting on primary sources such as observations and using secondary sources such as books, essays and so on.

\section{Water Productivity: Definition and Quantification}

\section{Terminology}

Water use efficiency and water productivity: The term "water use efficiency," means the ratio of crop production to evapotranspiration. The term has since become widely used to describe the yield (photosynthesis, biological, or economic) per unit of water (transpiration, evapotranspiration, or applied water). This agronomic view differs from the engineering definition in which water use efficiency means the ratio of the amount of water stored in the root zone divided by that delivered for irrigation. Irrigation engineers also use the term "irrigation efficiency" to designate the water required to grow a crop (i.e., evapotranspiration, percolation and seepage, leaching for salinity control and land preparation) divided by the water delivered.

Productivity, in general, is a ratio referring to the unit of output per unit of input. Economists refer to total factor productivity as the value of the production divided by the amount of all inputs. But the concept of partial productivity is widely used by economists and non-economists alike. This paper uses the term crop water productivity (WP) exclusively to denote the amount or value of the product over the volume or value of water depleted or diverted. Depending on how the terms in the numerator and denominator expressed, water productivity can be shown in general physical or economic terms as follows [2]:
- Pure physical productivity is defined as the quantity of the product divided by the amount of water depleted or diverted.

- Combined physical and economic productivity is defined in terms of either the gross or net present value of the crop divided by the amount of water diverted or depleted.

- Economic productivity is the gross or net present value of the product divided by the value of the water diverted or depleted, which can be defined in terms of its value or opportunity cost in the highest alternative use.

Within one context of water productivity (physical or economic), the choice of the denominator (depleted or diverted water) may vary with the objectives and domain of interest of the study.

Crop production is governed only by transpiration (beneficial depletion). If we could increase the product per unit transpiration everywhere in the domain of interest, production would rise without an increase in water depleted by agriculture.

Partial productivity of inputs: Agricultural policy reforms rationalized input and output prices and gave farmers control over cropping choices. Policy reforms thus gave farmers opportunities to increase production by changing cropping patterns or using inputs more efficiently. One measure of the efficiency of input use is increasing the productivity of inputs such as land, labor; machinery, nitrogenous fertilizer, and water contribute to growth in agricultural production. The partial productivity measure for a given input (water) in year $t$ is aggregate productivity in year $t$ divided by the quantity of the input (water) used in year $t$. It thus represents the average aggregate production per unit of the selected input.

Changes in cropping patterns may also have contributed to improved productivity of water inputs. Shifts in the cropped area from crops that make less efficient use of water and land resources to those that use these resources more efficiently may have contributed to the increased productivity of water.

Water productivity and water saving: Water-saving" measures often refer to technologies that lead to the reduction in the water supply to the domain of interest. It is important to realize that water saving doesn't necessarily lead to higher water productivity. Most of the so-called water-saving technologies aim at reducing the outflows from the domain of interest, without affecting crop (Evapo) transpiration (otherwise crop yield may be reduced) therefore, "water savings" may not affect the productivity per unit water depleted [3]. localized "water-saving" measures increase WP (Per unit water depleted or supply) at a larger scale, only if the "saved" water does not flow to a sink but is used productively elsewhere within the basin. In the previous example, where water savings lead to a reduction of water supplies to downstream highvalued crops, they lower the overall WP in the basin. Accordingly, the use of the term "water savings" is misleading, and changes in WP are site - and scale specific. At a local scale, farmers who benefit 
from WP-enhancing technologies may try to find ways to access more water to increase their profits. Legislative, institutional and economic measures may be needed to encourage adopting WPenhancing measure to increase productivity with the same of water supply, rather than to use more water to increase their income, at the expense of lower overall benefits and WP in the basin.

\section{Quantification of crop water productivity}

The productivity of water (PW): It can either be related to the physical mass of production or the economic value of production per unit volume of water. It is meaningful to compare values of the mass of production per unit of water diverted or depleted when comparing like crops. But when different crops are compared, the mass of output is not as meaningful. There is a clear difference between $1 \mathrm{~kg}$ of strawberries and $1 \mathrm{~kg}$ of rice produced per cubic meter of water depleted. One approach is to convert yields into the value of production using local prices.

A second approach is to use Standardized Gross Value of Production (SGVP). SGVP is used to measure economic productivity to allow comparisons across different agricultural settings by using world prices of various crops. To calculate SGVP, the yield of a crop is converted into an equivalent yield of a predominant, traded field crop using local prices. Then this mass of production is converted into a monetary unit using world prices [4].

We may increase crop productivity at the field level through improvement of on-farm water management, better crop husbandry, and advances in irrigation technology. Achieving high productivity for the water sector remains a challenge. The poverty of measurements used to assess productivity in terms of efficient management of national water resources beyond agricultural growth.

\section{Water Resources and its Uses in Some Arab Countries}

\section{Water resources}

The Arab region is the poorest in the world in terms of water resources; in this paper, a distinction has made between renewable and non-renewable water resources. Renewable water resources (RWR) are those resources generated from endogenous precipitation. Non-renewable water resources are groundwater bodies (deep aquifers) that have a negligible rate. Total renewable water resources (TRWR) are the total amount of a country's water resources and defined as the sum of internal renewable water resources (IRWR) and external renewable water resources (ERWR)

Renewable water resources: Renewable water resources (RWR) are those resources generated from endogenous precipitation:

The annual flow of rivers and lakes (surface water) and recharge groundwater reservoirs. Although the Arab countries cover $10.2 \%$ of the total area of the world, they receive only $2.1 \%$ of the world's average annual precipitation and have as little as $0.3 \%$ of its annual renewable water resources. Total annual internal renewable water resources (IRWR) accounted for only $6.3 \%$ of their average annual precipitation, against the world average of $40.6 \%$. The averages of internal renewable water resources per capita in the Arab countries are among the lowest in the world. The average for all Arab countries is $512 \mathrm{~m}^{3}$ /inhabitant per year, against $7243 \mathrm{~m}^{3} /$ year per inhabitant for the whole world. Internal renewable water resources per capita are below $500 \mathrm{~m}^{3}$ /year in 15 out of the 22 Arab countries.

Arab countries are still among the poorest in the world in terms of water resources. It is true considering the figures on total renewable water resources (TRWR). The average of actual TRWR is $1116 \mathrm{~m}^{3}$ /year. Actual TRWR per capita of the Arab countries is still significantly lower than the $7243 \mathrm{~m}^{3} /$ year of the world average. It is below $500 \mathrm{~m}^{3} /$ year in 12 countries reflecting an extreme variability: from a minimum of $10 \mathrm{~m}^{3}$ /inhabitant in Kuwait to more than $4000 \mathrm{~m}^{3} /$ inhabitant in Mauritania. Furthermore, some Arab countries depend to a large extent for their renewable water resources (RWR) on water flows originating outside their borders. This situation reflects a high dependency ratio of $54.2 \%$ in the group Arab countries.

Non- renewable water resources: Non-renewable water resources are groundwater bodies (deep aquifers) that have a negligible rate of recharge on the time- scale.

The distribution of surface water and groundwater illustrates the differences between arid and humid sub-regions. In arid subregions, such as the Arabian Peninsula, groundwater recharge is important and a critical factor for the development of their countries. On average, $62.8 \%$ of IRWR in the Arabian Peninsula is groundwater. On the other hand, in the less arid Arab countries with rivers, such as Sudan and Egypt where a large part of groundwater resources not connected to the river system.

The water scarcity that prevails in the arid Arab countries has forced the national authorities to find alternative ways to satisfy the demand for freshwater. Some Arab countries, particularly oilrich ones in the Arabian Peninsula, convert a significant amount of saline water from the sea or poor-quality aquifers (brackish water) into usable and even drinking water. The total use of desalinated water in the Arab countries is estimated at $1.7 \mathrm{~km}^{3} /$ year where three countries (Saudi Arabia, United Arab Emirates and Kuwait) are by far the most significant users of desalinated water, accounting for $78.6 \%$ of the total Arab countries Similarly, treatment and reuse of wastewater is becoming a common practice in some Arab countries, particularly in the Arabian Peninsula.

Arab countries with few renewable water resources are the dependence on major non-renewable groundwater basins. The non-renewable groundwater reserves located in large sedimentary aquifer systems represent an essential water resource for the arid zones in those countries due to the limited renewable water resources. They are particularly important for countries such as Algeria, Egypt, Libya, Palestine, Saudi Arabia, Tunisia, and the United Arab Emirates. Libya, which depends heavily on fossil groundwater 
to cover its current water demand. Therefore, the most significant part of the total water withdrawn in those countries is fossil water. However, although groundwater reservoirs may allow storage of vast quantities of water, they cannot be considered sustainable in the long term as the lack of present recharge would result in the gradual depletion of the aquifers.

Table 2: Water Resources in Some Arab Countries from Conventional Renewable and Non - Conventional Water Resources, Including Desalinized and Treated Waste Water.

\begin{tabular}{|c|c|c|c|c|c|}
\hline \multirow[b]{2}{*}{ Country } & \multicolumn{3}{|c|}{ Conventional Water Resource (MCM) } & \multicolumn{2}{|c|}{ Non-Conventional Water Resource (MCM) } \\
\hline & Surface Water & $\begin{array}{l}\text { Ground Water } \\
\text { Recharge }\end{array}$ & Ground Water use & Desalination & $\begin{array}{l}\text { Waste Water and } \\
\text { Drainage Reuse }\end{array}$ \\
\hline Lebanon & 2,500 & 600 & 240 & & 2 \\
\hline Oman & 918 & 550 & 1,644 & 51 & 23 \\
\hline West Bank and Gaza & 30 & 185 & 200 & 0.5 & 2 \\
\hline Yemen & 2,250 & 1,400 & 2,200 & 9 & 52 \\
\hline Jordan & 350 & 277 & 486 & 2.5 & 61 \\
\hline Saudi Arabia & 2,230 & 3,850 & 14,430 & 795 & $131(24)$ \\
\hline Qatar & 1.4 & 85 & 185 & 131 & 28 \\
\hline United Arab Emirates & 185 & 130 & 900 & 455 & 108 \\
\hline Iraq & 70,370 & 2,000 & 513 & 7.4 & 1,500 \\
\hline Syria & 16,375 & 5,100 & 3,500 & 2 & 1,447 \\
\hline Egypt & 55,500 & 4,100 & 4,850 & 6.6 & 3,800 \\
\hline Kuwait & 0.1 & 160 & 405 & 388 & 30 \\
\hline
\end{tabular}

Source: Musa N. NJMAH, "water resources [25]" in Arab environment: future challenges.

Water resources from conventional renewable and Nonconventional water resources in some Arab countries illustrated in the Table 2.

\section{Water withdrawal and use in agriculture}

Pressure on water resources: Total water withdrawal is the annual quantity of water withdrawn for agricultural, industrial and domestic purposes. The use of desalinated and treated wastewater included. Agriculture water withdrawal includes irrigation and livestock watering.

Water withdrawals in the Arab region went to support agricultural irrigated areas of no more than 14.25 million ha [5] which consume, on average, 85 percent of total water withdrawals with an average irrigation efficiency of 51 percent. Table 3, compared with a similar ratio of 72 percent in Northern Africa, 70 percent in East Asia, 67 percent in Eastern Europe, 57 percent in Northern America, and a World average of 56 percent [6].

Withdrawal of freshwater for agriculture in seven countries exceeds by far their annual renewable water resources, ranging between 103 percent in Egypt and 2,460 percent in Kuwait (Table 3 ). These high percentages indicate the countries' heavy reliance on fossil groundwater and rapid depletion of both renewable and non-renewable water resources. In highly water-stressed countries such as those of GCC, Libya, and Yemen, there are no prospects for increasing irrigated areas or even maintaining irrigation in current areas.

Table 3: Pressure on Water Resources: Water Withdrawal and use in Agriculture.

\begin{tabular}{|c|c|c|c|c|c|c|c|}
\hline $\begin{array}{l}\text { Country/Sub- } \\
\text { Region }\end{array}$ & $\begin{array}{c}\text { Actual } \\
\text { Renewable } \\
\text { Water } \\
\text { Resources } \\
\end{array}$ & $\begin{array}{c}\text { Total Water } \\
\text { Withdrawals }\end{array}$ & $\begin{array}{c}\text { Water } \\
\text { Withdrawal } \\
\text { Agriculture }\end{array}$ & $\begin{array}{l}\text { Irrigation } \\
\text { Water } \\
\text { Requirement }\end{array}$ & $\begin{array}{l}\text { Agriculture share } \\
\text { of total renewable } \\
\text { water resources }\end{array}$ & $\begin{array}{c}\text { Agriculture share } \\
\text { of the total with } \\
\text { drawls }\end{array}$ & $\begin{array}{l}\text { Irrigation } \\
\text { Efficiency }\end{array}$ \\
\hline & $\begin{array}{l}\text { (Million } \\
\left.\mathbf{M}^{3}\right)^{*}(1)\end{array}$ & $\begin{array}{l}\text { (million } \\
\left.M^{3}\right)^{*}(2)\end{array}$ & $\begin{array}{l}\text { (Million } \mathbf{M}^{3} / \\
\text { Yr) })^{* *}(3)\end{array}$ & $\begin{array}{l}\text { (Million } \mathbf{M}^{3} / \\
\text { Yr) }\end{array}$ & $(\%)^{*}(3 / 1)$ & $(\%)^{*}(3 / 2)$ & $(\%)^{* *}(4 / 3)$ \\
\hline Bahrain & 116 & 357.4 & 159 & 40 & 137.2 & 44.54 & 25.16 \\
\hline Kuwait & 20 & 913.2 & 492 & 119 & $2,460.00$ & 53.87 & 24.19 \\
\hline Oman & 1,410 & 1,321 & 1,168 & 721 & 83.43 & 88.42 & 61.73 \\
\hline Qatar & 58 & 444 & 262 & 76 & 451.7 & 59.01 & 29.01 \\
\hline Saudi Arabia & 2,410 & 23,670 & 20,830 & 11,599 & 867.91 & 88 & 55.68 \\
\hline $\begin{array}{l}\text { United Arab } \\
\text { Emirates }\end{array}$ & 150 & 3,998 & 3,312 & 1,815 & $2,208.00$ & 82.84 & 54.8 \\
\hline GCC & 4,164 & $30,703.60$ & 26,223 & 14,370 & 629.15 & 85.41 & 54.8 \\
\hline Yemen & 2,110 & 3,565 & 3,235 & 1,77 & 154 & 90.74 & 54.81 \\
\hline GCC\& Yemen & 6,274 & $34,268.60$ & 29,458 & 16,143 & 469.53 & 85.96 & 54.8 \\
\hline Iraq & 89,831 & 66,000 & 52,0 & 15,023 & 57.87 & 78.79 & 28.89 \\
\hline
\end{tabular}




\begin{tabular}{|c|c|c|c|c|c|c|c|}
\hline Jordan & 937 & 940.9 & 611 & 301 & 65.23 & 64.96 & 49.26 \\
\hline Lebanon & 4,503 & 1,310 & 780 & 529 & 17.32 & 59.54 & 67.82 \\
\hline $\begin{array}{l}\text { Occupied Palestinian } \\
\text { Territory }\end{array}$ & 837 & 418 & 189 & 93 & 22.58 & 45.22 & 49.21 \\
\hline Syria & 16,810 & 16,760 & 14,670 & 7,123 & 87.32 & 87.53 & 48.55 \\
\hline Levant & 112,918 & $85,428.90$ & 68,250 & 23,069 & 60.44 & 79.89 & 33.8 \\
\hline Egypt & 57,300 & 68,300 & 59,000 & 45,111 & 103 & 86.38 & 76.46 \\
\hline Sudan & 64,510 & 27,590 & 26,153 & 8,015 & 40.54 & 94.78 & 30.65 \\
\hline Nile Valley & 121,810 & 95,890 & 85,153 & 53,126 & 69.9 & 88.8 & 62.39 \\
\hline Algeria & 11,670 & 5,723 & 3,502 & 2,551 & 30.01 & 61.19 & 72.84 \\
\hline Libya & 710 & 4,326 & 3,584 & 1,833 & 517 & 82.85 & 51.14 \\
\hline Morocco & 29,000 & 12,610 & 11,010 & 5,823 & 37.97 & 87.31 & 52.89 \\
\hline Tunisia & 4,595 & 2,851 & 2,165 & 1,552 & 47.12 & 75.94 & 71.69 \\
\hline North Africa & 57,385 & 26,860 & 21,484 & 12,134 & 37.74 & 79.99 & 56.48 \\
\hline Comoros & 1,200 & 10 & - & - & 0.39 & 47 & - \\
\hline Djibouti & 310 & 19 & 85 & 51 & 1 & 15.79 & 60 \\
\hline Somalia & 14,700 & 3,298 & 820 & 263 & 22.32 & 99.48 & 32.07 \\
\hline African Horn & 16,210 & 3,327 & 905 & 314 & 20.29 & 98.85 & 34.7 \\
\hline Arab Region & 314,730 & $245,774.50$ & 205,250 & 104,786 & 65.97 & 84.48 & 51.05 \\
\hline
\end{tabular}

Source: *[16], (Year of data is different among countries, and covers the period 1999 for Comoros and 2006 for Saudi Arabia).

**[18], (Year of data is different among countries, and covers the period1990 for Iraq and 2006 for Kuwait).

According to FAO, countries are in a critical condition if they use more than 40 percent of their renewable water resources for agriculture and could be defined as water-stressed if they abstract more than 20 percent of these resources [7].

Based on this definition, most Arab countries are either in critical water condition or are water stressed. It is because abstraction from their renewable water resources for agriculture greatly overshoots the defined limits. For example, intensive use of non-renewable groundwater for agriculture and depletion of aquifers in Saudi Arabia led to the reduction of the area under cereal cultivation from about 4.53 million ha in 1980 to only about 301 thousand ha in 2012 [8]. Consequently, the country adopted a decision in 2008 to gradually phase out all water-intensive crops by 2016 [9].

\section{The Challenges of Food Security in Arab Countries}

Agricultural production depends on several factors, natural resources (land, water, and climate), human resources, machinery, equipment, seeds, and fertilizers. Furthermore, the institutional arrangements that improve the efficiency of markets and ensure continuous food supply.

\section{Water and food security challenges in the arab countries}

The total area of arable land in the Arab Countries is 197 million ha, of which currently about 71 million ha are under cultivation (about 36 percent). The cultivated area in 2008 has reached about 54 million ha. Rainfed agriculture makes around 75 percent of the total cultivated land and the balance of 25 percent is for irrigated agriculture. The distribution of crops is 60 percent grains, 5 percent vegetables, 8 percent fruit, 13 percent oilseeds, and the balance of 14 percent are for other crops. It is clear that the structure focuses on grains more than on other products.
Conditions of irrigated agriculture: The irrigation sector is the largest consumer of available water, as it uses about 187 billion $\mathrm{m}^{3}$ of water annually to irrigate about 14 million ha. Irrigated agriculture is mainly in Egypt, Sudan, Iraq, Syria, Morocco, Algeria, and Saudi Arabia, with a total irrigated area of about 12 million ha, or approximately 85 percent of the total irrigated area in the Arab World. Confronted with worsening conditions of expanding food gap during the seventies, the Arab countries, especially those with high agricultural potential, accelerated the process of surface and groundwater mobilization mostly for the purpose of expanding irrigation. The past three decades witnessed intensive exploitation of groundwater, including, non-renewable water, and construction of a large number of dams, especially in Iraq, Syria, Morocco, Algeria, Sudan, and Tunisia. This was accompanied by an expansion in irrigated areas, where the total of such areas increased from about 9.5 million ha in 1980 to approximately 14.2 million ha in 2008.

In spite of the fact that the irrigated area in the Arab World constitutes approximately 25 percent of total cultivated area, it contributes on average about 60 percent of the value of agricultural production. Water has contributed significantly to the reduction of the food gap and helped achieve self-sufficiency in vegetables and fruits.

Water management and food security challenges: Arab counties use about 215 billion $\mathrm{m}^{3}$ of water per year for agriculture, drinking, and industry, which constitutes about 77 percent of renewable available water. This is a high percentage and indicates that cost-effective water mobilization is close to its maximum. Indeed, the potential for further mobilization of water resources in most Arab countries is limited, as they have mobilized most of the water resources available at an acceptable cost. Most 
of the remainder is either marginal or expensive in terms of mobilization and transport. Limited possibility for mobilizing new water resources is still possible in countries like Algeria, Somalia, Morocco, and Mauritania, though in modest quantities compared to what has been used so far.

Although Arab countries use about 87 percent of water in agriculture, the Arab World is still far.

From achieving self-sufficiency in food, particularly cereals, with a cereals gap estimated in 2010 at about 60 million tons. It is expected that the food gap reaches in 2030 to about 120 million tons. For the Arab countries to achieve sufficiency in grains, vegetables, and fruit, it is estimated that there will be a need for additional quantities of water of not less than 220 billion $\mathrm{m}^{3}$. The above quantity does not include the future needs for drinking water and livestock production. The above-mentioned volume shows the limited water resources in the Arab World and its inability to achieve self-sufficiency in major crops. The volume also gives a realistic idea about the size and dimension of the water constraint that impedes the ability of the Arab region in meeting its food security challenge.

Agriculture in the Arab countries faces, in addition to the great waste in irrigation water, bad planning and poor coordination between water and agriculture sectors, poor organization of major irrigation facilities, and limited participation of farmers in the operation of irrigation systems. These factors negatively affect the performance of water and agriculture management.

Although the limited water resources in the Arab countries hinder achieving self-sufficiency in major crops, there is a way to reduce that gap significantly and to achieve acceptable food security. This may be achieved by raising irrigation efficiency and increasing the productivity of many agricultural crops, thereby increasing production by using the same quantities of water.

However, this solution requires good organizational and institutional arrangements that enable water and agriculture sectors to work in an integrated manner, develop plans and programs, and have clear water policies and directions aiming at optimizing the use of water.

\section{Institutional and organizational framework for water and agriculture sector development}

Organization and coordination between water and agriculture sectors: The absence of a comprehensive and integrated vision for the water sector, the agriculture sector, the lack of strategies, and specific programs to manage both areas have adversely affected their performance in many Arab countries. The functions of several institutions and various government bodies overlap in the management of water without adequate coordination. The results in fragmentation of the regulatory framework and laws relating to water and agriculture sector and lead to weak and improper planning and management of water. There is a need for coordination of water and agriculture policies in a context of clear strategies and targets, which directed towards improving the allocation of water resources and the efficiency of their use.

Institutional arrangements relating to irrigation water: The institutional arrangements relating to irrigation water mainly refer to the management of irrigation facilities and systems. Government agencies, and sometimes central departments, in many Arab countries, manage irrigation networks. Such networks suffer from poor maintenance and mismanagement due to lack of proper staff. International experiments have shown the relative success of irrigation management programs in partnership with farmers to support the implementation of those programs. This arrangement is usually carried out by "water user associations", which are financially independent and responsible for the operation and maintenance of irrigation networks, water distribution, and collection of the proceeds of the sale of water, the water user associations used in some Arab countries like Egypt, Jordan, Libya, Morocco, Oman, Tunisia, and Yemen. Given the relative success of these arrangements, their activities should be extended to include other aspects of infrastructure for irrigation.

\section{Financing food and water security}

Investments in water represented 46 percent of all agricultural spending in the region. Investment in agricultural finance has dropped by almost half from 2000-2003 levels. This reduction; however, reflects in part a number of policies shifts which have moved away from commodity-targeted credit in favor of broadening and deepening general financial services, and this aid is therefore no longer identified as specifically agriculture-related.

It can be costly for financial institutions to service farmers because they are physically difficult to reach. Rural clients are usually scattered across wide geographic areas, posing significant logistical challenges for urban-based banks. The development of flexible distribution channels to deliver and monitor loans is critical for sustainable agricultural finance [10].

\section{Investment in research}

Investment in research and development has many social benefits, including enhanced food and nutrition security and improved rural livelihoods. Its benefits farmers as well as food consumers. The rate of return on investment in research and development in Arab countries is at 36 percent. Hence, it is surprising that Arab governments appear not to assign a high priority to research. Arab countries invest about $\$ 1.4$ billion U.S. annually, or 0.7 percent of agricultural GDP, in research and development, it is far below the internationally recommended level of 2 percent of agricultural GDP as well as the level of investment in developed countries which averages 2.4 percent of agricultural GDP.

Arab countries need to finance and support an ambitious multilateral research agenda. Arab states share the same goal of food, nutrition security and face the same challenge of water scarcity; a multi-nation initiative could increase the number of 
beneficiaries from a joint research agenda. Investments in research and development need to couple with improvements in extension which must reach large and small farmers alike.

\section{Strategies for Improving Crop Water Productivity}

Achieving food security via improving water productivity can be implemented through several options, supported by the adoption of right policies, practices, and suitable techniques.

\section{Raising the efficiency of irrigation water}

Water in agriculture in the Arab World is generally characterized by low efficiency, where conventional surface irrigation (about 80 percent of the irrigated area) is the dominant system; particularly in countries of major agricultural production. Improving irrigation efficiency to produce more crops with less water is an option of significant importance for enhancing food security in water-scarce countries. Addressing water use efficiency could be a complicated task which requires the identification of the underlying principal factors that influence the efficiency of the components of the water delivery system, including water conveyance and water application in the field. FAO points out that conveyance efficiency is influenced by the length of canals, the soil type in which the canals are dug, and field application efficiency is mainly dependent on the irrigation method and the level of farmer discipline.

Using modern irrigation system: Using modern irrigation techniques can help avoid the use of excess water over the crops' requirements, which is not less than 20-25 percent of the amount of water used in surface irrigation. It is noteworthy that irrigation efficiency does not depend on the use of modern technologies within the farm, where water transport lines and main irrigation lines are inadequate due to poor maintenance. Such networks should be rehabilitated and, if necessary, replaced, in order that water loss, which in some cases reaches up to 30 percent of the quantities used, may be reduced.

government investment for the rehabilitation existing facilities and networks, investments to be made by farmers relating to the irrigation system, drip or sprinkler, inside the farm. The farmers may not be encouraged to do so due to lack of financial ability and ignorance of the economy behind it. Furthermore, the installations of drip and sprinkler irrigation require competence and experience for their operation, and also require the development of programs of awareness and guidance for farmers, particularly in the early years of introducing these new systems to them. Therefore, there is a need to develop integrated institutional programs in which farmers should be included. But above all, incentives should be established in order to encourage farmers and attract them to use the new technologies.

\section{Increasing crop productivity}

Using modern irrigation techniques can help avoid the use of excess water over the crops' requirements, which is not less than 20-25 percent of the amount of water used in surface irrigation. It is noteworthy that irrigation efficiency does not depend on the use of modern technologies within the farm, where water transport lines and main irrigation lines are inadequate due to poor maintenance. The irrigation networks must be maintained, rehabilitated, and if necessary, replaced to reduce water loss, which in some cases reaches up to 30 percent of the quantities used.

Government must investment for the rehabilitation of existing facilities and networks. Meanwhile, the farmer has to invest for on-farm relating to the irrigation system, drip or sprinkler, inside the farm. The farmers may not be encouraged to do so due to lack of financial ability and ignorance of the economy behind it. Furthermore, the installations of drip and sprinkler irrigation require competence and experience for their operation, and also require the development of programs of awareness and guidance for farmers, particularly in the early years of introducing these new systems to them. Therefore, there is a need to develop integrated institutional programs in which farmers should include. But above all, incentives should be established to encourage farmers and attract them to use the new technologies.

The decline in consumption of water per hectare: Up to the year 2000, the average consumption per hectare of water has decreased by about 7 percent. ( 5 percent for vegetables and 9 percent for fruit trees) as a result of using drip irrigation. The decline varies greatly depending on the crop. The development of the average consumption of water per hectare is declined from about $6000 \mathrm{~m}^{3} /$ hectare in 1990 to about $4800 \mathrm{~m}^{3} /$ hectare in 2009 (-20 percent).

\section{Improving water productivity}

Water productivity is measured either in physical or economic terms. Economic water productivity considers the allocation of water to higher value crops, whereas, physical water productivity disregards crop value and focuses on 'more crop per drop'. The choice between those two water productivity indicators is country specific. It depends on whether crop quantity or crop value is more relevant to a state within the broader political, economic, social, and environmental aspects of food security.

Improving crop yields is a crucial option for enhancing selfsufficiency in such staple food as cereals. However, it is essential to note that maximizing crop water productivity requires complementing and reinforcing water with a composite of factors, such as the adoption of efficient and modern irrigation schemes, coupled with best farming practices and improved inputs conducive to agricultural sustainability. "There are various kinds of improved agricultural practices, such as drip and sprinkler irrigation, no-till farming and improved drainage, utilization of the best available germplasm or other seed development, optimizing fertilizer use, innovative crop protection technologies, and extension services" [11].

Moreover, farming practices such as water harvesting, deficit irrigation, water conservation, and organic agriculture are not only conducive to raising water productivity, but they are also significantly crucial for agricultural sustainability. The adoption of the principle of maximizing the economic return on the water in the allocation of water resources requires improving water 
productivity by raising the efficiency of its use and using modern irrigation techniques, in addition to deciding appropriate policies and incentives, especially water pricing policies.

\section{Improving Rain-fed crop productivity}

Rain-fed agriculture in the Arab region is practiced on nearly75 percent of the cultivated area (AQAD). The productivity of such crops as cereals in rain-fed land is very low compared to that in irrigated areas. Cereal production in most Arab countries is largely dependent on rain-fed systems. Improving rain-fed cereal yield is significance to enhancing self-sufficiency in cereals.

FAO points out that the potential to improve yields depends strongly on rainfall patterns, yet in dry areas, rainwater harvesting can both reduce risk and increase yields. It refers to various forms of rainwater harvesting including in situate conservation, flood irrigation, and storage for supplementary irrigation. Special attention should be directed towards water harvesting, which includes-in particular-the establishment of small dams and excavation of mountains' lakes to collect all possible rainwater to be used in rural areas, so that agriculture becomes a source of income, thus contributing to the improvement of the living conditions of populations in those areas.

\section{Virtual water}

The concept of virtual water refers to the embedded water in the production of agricultural products. It postulates an option for water-scarce countries to counter food security issues by importing water-intensive food products and using their limited internal water resources for the production of high-value and less water-intensive commodities. It is an economic thesis that does not address the broader political, social and environmental aspects of food security.

The virtual water concept, it remains useful in the context of a country's water situation, and the overall role of agriculture in economic and social development.

\section{Improved crop varieties}

A large number of improved crop varieties have developed. The new types offer a range of valuable traits that are directly relevant under the environmental conditions in the Arab region, offering higher and more stable yields, ability to survive harsh conditions, and with climate change adaptation traits:

- $\quad$ High yield potential and yield stability;

- Agronomic traits such as earliness, improved canopy architecture;

- Tolerance to abiotic stress such as drought, heat, cold and salinity; and

- Resistance/tolerance to biotic stresses (diseases, insect pests, parasitic weeds).

\section{Intra-regional cooperation}

Varying land and water resources endowments in the Arab region provide a great alternative to enhance food security base on exploiting the real comparative advantage in food production. Arab countries have over the past decades expressed their willingness to promote Arab cooperation to advance regional food security. The Arab countries in the region should also benefit from each other's experiences in water savings, from the increases in productivity and the promotion of agricultural exports.

To be effective, intra-regional cooperation in food security requires an approach based on the harmonization of national agricultural strategies and policies, implementation of agrarian practices, regulations, measures, and incentives conducive to the efficient use of resources with particular attention to the improvement of the management of shared regional water resources. Conservation of the productive bio-capacity of land and water resources is a pre-requisite for agricultural sustainability which is the cornerstone for food production at the national, subregional, and regional levels. While availability security, facilitation of intra-regional agricultural trade through reduction or elimination of trade barriers, improved marketing information, and provision of infrastructure for communication and transport are of critical importance for accessibility to food.

\section{Increasing Adopting of Water Productivity}

\section{Enhancing technologies, socioeconomic and institutional requirements}

This paper has identified several measures and options that are available to farmers, managers, social organizers and politicians that have the potential of increasing WP. However, some steps have been adopted or have been adapted to local circumstances, while others have remained largely untested. The details for successful adoption or adaptation need to study in the broader range of conditions. The need for farmers' participation in irrigation management has established. The type of institutional arrangement that will promote farmers adoption of WP-enhancing measures is a worthy topic of research.

The need for farmers' participation: The farmers needs to know the change process from its very beginning. Where measures are not ready yet for adoption, more work needs to do before introducing them to the farmers.

Several conditions for success in the organization of water users in irrigation systems have identified, and they are probably also relevant to the change processes involved in the adoption of WP enhancing measures in both rain-fed and irrigated areas. The conditions include government commitment and sustained support from the bureaucracy to the establishment of new institutional arrangements. The responsibility needs to express through rules and regulations, which have been developed preferably by the farmer groups themselves, and have the power of law, have been accepted by the parliament and will be strictly enforced. The initial development of farmers' groups has been found to require social organizers as well as extensive training of the farmers such that they are empowered to make well- informed choices within a strict set of rules [12]. Where measures are ready, and adoption is not as widespread as expected, the reasons for it need to be studied. 
Socioeconomic aspects: When considering the socioeconomic aspects of adoption of WP-enhancing measures, the benefits and the costs need to ascertain. Everyone agrees with the now famous proclamation of the 1992 Dublin Conference that water "should be treated as an economic good." But how this can be reconciled with the concept of water as a social good., a basic human need that should be exempt from competitive pricing and allocation, still eludes us. The compromise appears to find in accepting that water is both an economic good and a public good that requires some amount of extra-market management to serve social objectives. This value judgment complicates decisions as to how to allocate and price water to increase its productivity. It's made it very complicated to determine whether or not it is advantageous for society to encourage the adoption of a specific new watermanagement technology.

Institutions and policies: Policies and incentives are as relevant in the adoption of WP- enhancing measures as they were found to be in the adoption of conservation agriculture [13-19]. FAO concludes that the financial benefits that accrue from changes in cultural practices often take a long time to materialize; farmlevel factors vary from farm to another; and that higher-level factors are also at work, such as the transmission of information (via policy-related activities and social processes). Especially noteworthy is that the inconsistent and, sometimes, contradictory results obtained from studies on the adoption of new practices tend to suggest that the decision-making process is highly variable , it is essential to understand this decision-making process better., as it will affect the lead-time from study to field practice, which at present is often unacceptably long, considering the urgent character of water scarcity problems . Experience from elsewhere in participatory research and extensions may help reduce this lead-time. Actual rates of adoption are often specific to people, places, and situations [20-26]. This makes the task of developing a policy framework to promote adoption of WP-enhancing measures particularly challenging.

\section{Conclusions and Recommendations}

\section{Conclusion}

- The factors driving food security in the Arab region are:

- Enabling policy environment and political support for agriculture;

- Investment in research, to harness science to sustainably increase food production;

- Investment in agricultural infrastructure and development;

- Sustainable intensification of production systems;

- Extension and effective technology transfer mechanisms;

- $\quad$ Capacity development and institutional support. And

- Innovative partnerships and networking.

- Adoption of policies, farming practices, and adapted technologies within a framework of laws, rules, and regulations conducive to the efficient and sustainable utilization of land and water resources[27-30].

- Efficient water saving programs by increasing irrigation efficiency through rehabilitation and timely maintenance of water transport systems, and the use of more effective irrigation methods like land leveling for higher yield surface irrigation or using more efficient technologies Like sprinkler and trickle irrigation.

- Modernization of agricultural production is essential. This requires a greater investment,

- basic infrastructure, education, research, and extension. Farmer education and involvement in the development and dissemination of new technologies is critical.

- Boosting crop productivity in irrigated and rain-fed systems, especially cereals, is key to enhancing food selfsufficiency and call for providing adequate funding for agricultural research institutions and organizations to intensify their research for developing high yielding, saltresistant, and drought-tolerant crop varieties

- Improving water productivity by producing more crop with less water requires knowledge-based farming practices, farmer discipline on farm water-saving methods and incentives, including appropriate pricing for water irrigation.

- Acquiring food through the 'virtual water 'concept requires a thorough evaluation of its political, economic, social, and environmental implications, especially its impact on domestic agriculture and the role it plays in the development of the national economy.

- Introducing low-water-consuming crops, introducing salt-tolerant crops, and reuse of drainage. Intensifying cropping pattern was one of the contributions of the factors to increase water productivity.

- Change the attitude towards regional cooperation, encourage and improve Arab coordination, harmonization of policies and management. Water productivity can be enhanced if food is grown in Arab countries with comparative advantages in water, climate, soils and socioeconomic [31].

\section{Recommendations}

- Having a clear strategy among the Arab countries aims to increase the food storage within mutual agreements.

- Effective strategies for obtaining more productivity while maintaining or improving the environment must be formulated

- Using developed methods in agriculture and exploiting the lands and establishing dams and gathering rainwater.

- Implementation of an optimal water productivity strategy that leads to the import of water through virtual water. 
- A major investment plan is needed to modernize the irrigation and drainage sector. In addition, large investments are urgently required in supplementary irrigation for the rain-fed land.

- Each country mustdesign and implementa comprehensive national strategy for agricultural development taking into consideration the available land and water resources and proven currently technologies.

- Special programs to encourage farmers to adopt modern irrigation systems; there should be a government program (supported by regional and international funding agencies) which supports the farming communities in the introduction of water-efficient systems.

- The more effort must be made in the future to produce crops able to deliver increased yields under drought conditions, in the areas of crop physiology, genetic and molecular biology with the state-of-the-art breeding technologies.

- A comprehensive regional program must be established to enhance food security. This would include regional and or sub-regional components, building on complementarities and comparative advantages of each country.

- The role of scientific research should take its place to develop new affordable desalination techniques. The same role is significant for introducing new agriculture seeds and breeds that have high productivity, high disease.

\section{Acknowledgement}

None.

\section{Conflict of Interest}

No conflict of interest.

\section{References}

1. Arab Planning Institute (2004) Foreign direct investment, definitions and issues, Kuwait: 8

2. JW Kijne, TP Tuong, J Bennett, B Bouman, T Oweis (2003) Ensuring Food Security via Improvement in crop water productivity. challenge program on water and food. Background paper 1

3. FAO (2001) The economics of conservation agriculture. Rome, Italy, Land, and Water Development Division, Food and Agriculture Organization of the United Nations.

4. David Molden (1997) Accounting for water use and productivity. SWIM paper, System-Wide initiative for water Management (IIMI), International Irrigation Management Institute, Colombo, Seri Lanka, Colombo, Sri Lanka, pp. 1-26.

5. AOAD (2012) Arab Agricultural Statistics Yearbook, Arab Organization for Agricultural Development (AOAD), Khartoum, Volume 32.

6. FAO (2014b) AQUASTAT database. Water requirement ratio by region. Food and Agriculture Organization (FAO), Rome.

7. FAO (2002) Crops and Drops: Making the best use of water for agriculture. Food and Agriculture Organization (FAO), Rome.

8. FAO (2013a) Food FAOSTAT database and Agriculture Organization (FAO), Rome.
9. FAO (2014c) GIEWS Country Briefs: Saudi Arabia. Food and Agriculture Organization (FAO) Rome.

10. Dellien, Hans and Elizabeth Lynch (2007) Rural Finance for Small Farmers: An Integrated.

11. Future Water (2011) Middle-East and North Africa Water outlook

12. Molden D, Oweis T, Steduto P, Kijne J, Hanjra M, et al. (2007) Pathways for increasing agricultural water productivity. Chapter7 in Water for Food, Water for Life-a comprehensive asse00ssment of water management In Agriculture, UK

13. Approach. New York: Women’s World Banking.

14. FAO (2010) The State of Food Insecurity in the World: Addressing Food Insecurity in Protracted Crises. FAO: Rome.

15. FAO (2011) The State of Food and Agriculture: Women in Agriculture, Closing the Gender Gap. FAO: Rome.

16. FAO (2013) Water in the Arab Region: Availability Status and Threats. (Chapter 1) in Water Governance in the Arab Region: Managing Scarcity and Securing the Future.

17. FAO (2014) FAO Food Price Index. Food and Agriculture Organization (FAO), Rome.

18. FAO (2014a) AQUASTAT database. Water requirement ratio by country. Food and Agriculture Organization (FAO), Rome.

19. FAO (2015) The State of Food Security and Agricultural Resources (chapter 1) by Abdul Karim Sadik, Arab Environment Food Security

20. Gamal El Afandi, Fouad A Khalil, Samiha A Ouda (2010) Using Irrigation Scheduling to increase water productivity of wheat-Maize Rotation Under Climate change conditions. CHILEAN Journal of Agricultural Research 70(3): 474-484

21. Gamal M Fawzy (2013) Policy Analysis of Recommended water management. water Management Research Institute (WMRI), National Water Research Center (NWRC) and ICARDA/Cairo-Egypt.

22. Hans, Elizabeth Lynch (2007) Rural Finance for Small Farmers: An Integrated Approach. New York: Women's World Banking.

23. IFAD (2009) Fighting Water Scarcity in the Arab Countries, International Fund for Agricultural Development, Contact by Tayser Al Ghanam and Mylene Kherallah, Italy.

24. Economic \& Social Development (2012) Food and Water Security in the Arab World, in Proceeding of the First Arab Development, edit by Atif Kubursi.

25. Nabil Dabor (2006) water resources and their use in agriculture in Arab countries. Journal of economic cooperation 27(1): 1-38.

26. Oweis T, A Hachum (2009) Optimizing supplemental irrigation: tradeoffs between profitability and sustainability. Ag W Mgt 96: 511-516.

27. Rockström J, Karlberg L, Wani P, Barron J, Hatibu N, et al. (2010) Managing water in rainfed agriculture - the need for a paradigm shift. Ag W Mgt 79: 4-5.

28. Shawki Barghouti (2008) Water Productivity: Challenges Facing Agricultural development - the changing paradigm of water use. Water for food Quantity and Quality in changing world, the international forum on water policy $6^{\text {th }}$ forum Agenda Zaragoza, Spain.

29. Wenner, Mark D (2010) Credit Risk Management in Financing Agriculture. In Innovations in Rural and Agriculture Finance, ed. R Kloeppinger-Todd and M Sharma, Brief 10, Washington.

30. World bank (2005) A Water Sector Assessment Report on the Countries of the Cooperation Council of the Arab Gulf Water Environment, Social and Rural Development Department Middle East and North Africa Region.

31. World Bank, FAO, IFAD (2009) Improving Food Security in Arab Countries. The World Bank: Washington DC, Food and Agricultural Organization (FAO), Rome, International Fund for Agricultural Development (IFAD), Rome. 